\title{
Lugano Classification Stage IV Childhood Hodgkin Lymphoma AJCC v8
}

National Cancer Institute

\section{Source}

National Cancer Institute. Lugano Classification Stage IV Childhood Hodgkin Lymphoma

A/CC v8. NCl Thesaurus. Code C141187.

Stage IV: Diffuse or disseminated involvement of one or more extralymphatic organs, with or without associated lymph node involvement; or noncontiguous extralymphatic organ involvement in conjunction with nodal stage II disease; or any extralymphatic org an involvement in nodal stage III disease. Stage IV includes any involvement of the bone marrow, liver, or lungs (other than by direct extension in stage IIE disease). (from AJCC 8th Ed.) 